E Q U I L I B R I U M

2 ( 5 ) 2010

ISSN 1689-765X

Bartosz Bartniczak

\title{
The Role of the European Union Support in Implementing of the Provisions of the National Environmental Policy in the Years 2004-2006
}

Key words: state environmental policy, the Cohesion Fund, structural funds, expenditure on environmental protection

\begin{abstract}
Environmental protection is one of the major challenges of the modern world. However, a different situation can be observed in Poland. The document which sets out the aims and objectives to be achieved in this area is the National Environmental Policy. The article presents what the main goals of this policy are and shows the sources of its funding. A detailed analysis of the financing of the environmental policy with the aid of the European Union was carried out. The studies have shown that there is too little spending on environmental protection and the provisions of the National Environmental Policy cannot be fully realized.
\end{abstract}

\section{INTRODUCTION}

Politics in general is statecraft or activities of government which is aimed at achieving or defending a particular purpose (Górka, Poskrobko, 1998, p. 63). With the emergence of new problems requiring government intervention from the general policy of the state, we can distinguish, for example, regional policy, social policy, agricultural policy, industrial policy and environmental policy (Bernaciak, Gaczek, 2002, p. 122). It is understood that an environmental policy is a deliberate and purposeful activity of the state, which relies on the rational use of resources and the value of the natural environment, its proper protection and skilful shaping based on theoretical and practical knowledge acquired by mankind (Górka, Poskrobko, 1998, p. 65).

The main objective of any national environmental policy is to ensure the ecological security of the country through the following: rationalization of water use, reducing materials consumption and waste from production, reducing 
energy intensity of the economy and increase use of renewable energy, soil protection, protection of mineral resources, rational exploitation of forest resources (Sobiecki, p. 35).

The document binding currently is the National Environmental Policy for 2003-2006 and its 2010 outlook. (Polityka Ekologiczna Państwa). The document outlined the aims and objectives of the system which contained the inclusion of environmental aspects into sectoral policies, activating the market for environmental actions, economic mechanisms and funding systems, institutional strengthening, public participation and environmental education, access to information and broadening the social dialogue development, greening of urban planning and land use, development of research and technological progress, stimulating innovation, and international cooperation.

Also, these were mentioned various fields of environmental protection which were identified in the initial state as the medium-term targets for the year 2010 and the tasks for realization in the period 2003-2006.

\section{Predicted expenditures AND SOURCES OF FinANCING the National Environmental Policy}

The total cost of the policy implementation in the period 2003-2010 is expected to be about 140 billion PLN. This means that the average annual expenditure during this period should amount to 17.8 billion PLN. The amounts invested and divided into various kinds of activities are presented in Table 1.

Table 1. Expenditures for the implementation of National Environmental Policy in the years 2003-2006 and 2007-2010 by activities

\begin{tabular}{|l|c|c|c|c|}
\hline \multirow{2}{*}{ Activities } & \multicolumn{3}{|c|}{ Expenditure in millions PLN } \\
\cline { 2 - 5 } & non-investment projects & investment projects \\
\cline { 2 - 5 } & $2003-2006$ & $2007-2010$ & $2003-2006$ & $2007-2010$ \\
\hline Rationalization and use of resources & 37 & 49 & 8900 & 12000 \\
\hline $\begin{array}{l}\text { Reducing water consumption, materials } \\
\text { consumption and energy intensity of } \\
\text { economy }\end{array}$ & 11 & 14 & 120 & 160 \\
\hline $\begin{array}{l}\text { Soil protection and rehabilitation of } \\
\text { degraded areas }\end{array}$ & 67 & 88 & 600 & 800 \\
\hline $\begin{array}{l}\text { Enrichment and rational utilization of } \\
\text { forest resources }\end{array}$ & 58 & 77 & 12500 & 16600 \\
\hline Improving the quality of the environment & \multicolumn{3}{|l}{} \\
\hline Waste management & 58 & & & \\
\hline
\end{tabular}


Table 1 - continued

\begin{tabular}{|c|c|c|c|c|}
\hline \multirow{3}{*}{ Activities } & \multicolumn{4}{|c|}{ Expenditure in millions PLN } \\
\hline & \multicolumn{2}{|c|}{ non-investment projects } & \multicolumn{2}{|c|}{ nvestment projects } \\
\hline & $2003-2006$ & $2007-2010$ & $2003-2006$ & $2007-2010$ \\
\hline Water relations and water quality & 170 & 220 & 17000 & 22500 \\
\hline Air Protection against Pollution & 87 & 120 & 8500 & 11200 \\
\hline $\begin{array}{l}\text { Comprehensive efforts to introduce the } \\
\text { best available techniques in industry }\end{array}$ & - & - & 11500 & 15200 \\
\hline Urban stress, noise and radiation & 21 & 28 & 1300 & 1700 \\
\hline $\begin{array}{l}\text { Chemical and biological safety. Major } \\
\text { industrial accidents }\end{array}$ & 170 & 220 & 2 & 2 \\
\hline $\begin{array}{l}\text { Nature conservation and biodiversity } \\
\text { and landscape }\end{array}$ & 270 & 350 & 110 & 140 \\
\hline \multicolumn{5}{|l|}{ Tools and instruments for implementation } \\
\hline $\begin{array}{l}\text { Environmental Protection Law and its } \\
\text { adaptation to the requirements of the } \\
\text { European Union }\end{array}$ & 1 & 2 & - & - \\
\hline $\begin{array}{l}\text { Mechanisms of economic and financial } \\
\text { environment }\end{array}$ & 3 & 5 & - & - \\
\hline Management, control and monitoring & 240 & 310 & 4 & 5 \\
\hline $\begin{array}{l}\text { Research and technological progress. } \\
\text { Access to information and public par- } \\
\text { ticipation. Environmental Education }\end{array}$ & 12 & 16 & - & - \\
\hline Foreign cooperation & 100 & 140 & - & - \\
\hline $\begin{array}{l}\text { Executive programs and update the } \\
\text { National Environmental Policy }\end{array}$ & 1 & 1 & - & - \\
\hline Total & 1248 & 1640 & 60536 & 80307 \\
\hline
\end{tabular}

Sources: Polityka Ekologiczna Państwa na lata 2003-2006 z uwzględnieniem perspektywy na lata 2007-2010 (2002), The Council of Ministers, Warsaw 2002, p. 67.

Estimated forecasts for financing the implementation of National Environmental Policy in the years 2003-2010 are presented in Table 2. Expenditures on environmental protection and water treatment generated in the country in conjunction with the planned and possible to obtain foreign aid, particularly aid funds, structural funds and the Cohesion Fund will be sufficient to finance the implementation of the enterprises provided in this policy (Polityka Ekologiczna Państwa - The State's Environmental Policy). 
Table 2. Projected expenditure on the implementation of the National Environmental Policy in the years 2003-2010 according to the sources of funding

\begin{tabular}{|l|c|c|c|c|c|c|c|c|c|}
\hline Specification & 2003 & 2004 & 2005 & 2006 & 2007 & 2008 & 2009 & 2010 & Total \\
\hline $\begin{array}{l}\text { Own resources of } \\
\text { enterprises }\end{array}$ & 5459 & 6488 & 7448 & 8529 & 8858 & 8858 & 8859 & 8859 & 63358 \\
\hline $\begin{array}{l}\text { Measures of local } \\
\text { government units }\end{array}$ & 1086 & 1188 & 1299 & 1445 & 1585 & 1849 & 1982 & 2137 & 12571 \\
\hline State budget & 844 & 904 & 964 & 995 & 1379 & 1598 & 1787 & 1995 & 10466 \\
\hline $\begin{array}{l}\text { Environmental } \\
\text { funds }\end{array}$ & 2837 & 3250 & 3250 & 3390 & 4550 & 4549 & 4549 & 4549 & 30924 \\
\hline $\begin{array}{l}\text { Foreign assistance } \\
\text { (including pre- } \\
\text { accession) }\end{array}$ & 750 & 750 & 720 & 108 & 108 & 72 & 72 & 72 & 2652 \\
\hline $\begin{array}{l}\text { Cohesion Fund and } \\
\text { Structural Funds }\end{array}$ & - & 3060 & 3420 & 3600 & 3600 & 3600 & 3240 & 3240 & 23760 \\
\hline Total & 10976 & 15640 & 17101 & 18067 & 20080 & 20526 & 20489 & 20852 & 143731 \\
\hline
\end{tabular}

Sources: Polityka Ekologiczna Państwa na lata 2003-2006 z uwzględnieniem perspektywy na lata 2007-2010 (2002), The Council of Ministers, Warsaw 2002, p. 68.

A breakdown of expenditures shows that the main burden of financing the National Environmental Policy will be put on the own resources of enterprises (Figure 1). The second source of funding will be based on ecological funds (funds for environmental protection and water management). Another source are the aid resources from the European Union which will be directed to the environmental sector.

Figure 1. The structure of funding for national environmental policy in the years 2003-2010

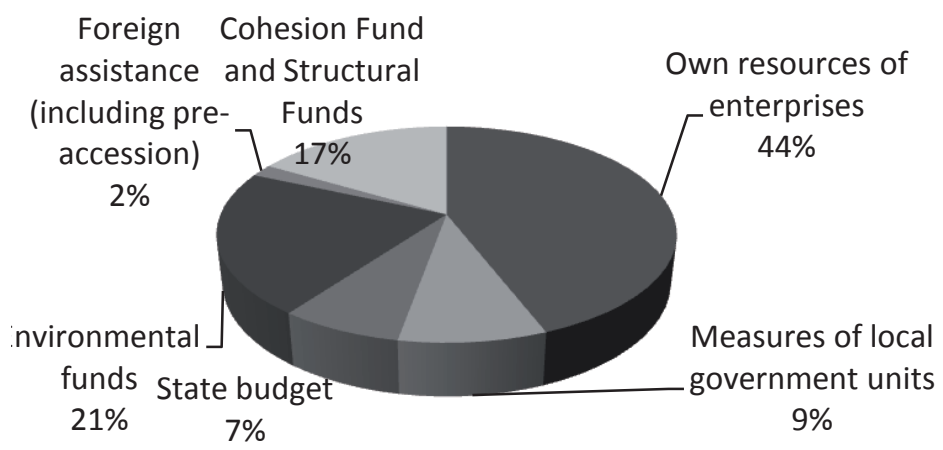

Source: own study based on Polityki Ekologicznej Państwa na lata 2003-2006 z uwzględnieniem perspektywy na lata 2007-2010 (2002), The Council of Ministers, Warsaw 2002, p. 68. 
The analysis shows that the estimation for the implementation of the national environmental policy in the years 2004-2006 was 50.8 billion PLN of which nearly $20 \%-10.1$ billion PLN came from the Cohesion Fund and structural funds.

\section{The role of the Cohesion Fund in Supporting environmental investments in Poland in the years 2004-2006}

The Cohesion Fund is an instrument of prime importance from the perspective of social and economic cohesion of the European Union as a whole. It aims to support the countries whose GNP per capita does not exceed $90 \%$ of the Community average. Projects supported by the Cohesion Fund in the less developed EU countries are to contribute to the development and modernization of transport and environmental infrastructure, and, due to it - the realization the objectives of the European transport and environmental policy as cohesion policy objectives aimed at reducing economic and social disproportions between different countries. Such understanding of Community intervention in this area also reflects the philosophy of sustainable development, particularly increasing the productivity and competitiveness of the economy mainly through the development of transport infrastructure, but also not to the detriment of the environment and its resources, and thus - at the expense of future generations. Justification for intervention in the environmental sector stems from the fact that if growth continues in a long term, there are needed long-lasting environmental conditions. Indeed, if this increase has a detrimental impact on the environment, it will result in a reduction of development. Quality, availability of natural environment and state connected with this infrastructure (e.g., water supply system) are also key elements of quality of life, and thus affect social cohesion. Implementation of environmental policy is also an opportunity to jobs creation as well seasonal as permanent distribution effects in geographical and social dimension. So the availability of natural resources and means taken to protect the environment are the factors determining long-term productivity and efficiency of economies and in consequence - economic and social cohesion.

According to the European Union summit in Copenhagen in December 2002 on the obligations of the European Union from the Cohesion Fund for the years $2004-2006$, there were provided 3,733.3 million euro (in 1999 prices), of which in 2004 - 1,277.6 million euro; in 2005 - 1,051.9 million euro, in 2006 - 1,403.8 million euro, national co-financing amounted to 1,129.5 million euro. From these obligations to activities in the area of transport infrastructure, the pre-allocated sum was 1,866.7 million euro, in the area of environment protection 1,866.6 million euro. These funds were spent on large projects or groups of projects forming a coherent whole, which significantly affect the trans-European transport 
network development and environmental improvement, bringing it closer to the standards established by the organic law of the Community whose budget is not less than 10 million euro.

Actions taken in the field of environmental protection during the Polish accession to the European Union were targeted at the Community environmental policy objectives set out in Article 174 of the Treaty of Amsterdam that is: to preserve, protect and improve the quality of the environment, protect human health, economical and rational use of natural resources, which in long term will affect the implementation of the paradigm of sustainable development. Article 2 of the Treaty of Amsterdam, in turn, stresses that the objectives of the Community are to ensure a high level of protection and environmental improvement. Furthermore, according to the provision of Article 6 requirements of environmental protection must be included in the definition and implementation of Community policies and activities, particularly in terms of promoting sustainable development.

The leading purpose of the activities in the area of environmental protection in the 2004-2006 period was to reduce the gap between Poland and Western Europe in the field of environmental quality standards and the technical and institutional infrastructure in this area. The priorities for environmental protection proposed for the support from the Cohesion Fund for the period $2004-2006$ were as follows:

- improving the quality of surface water, improving the quality and distribution of drinking water,

- rationalization of waste management and land protection,

- improving quality of air,

- improving flood safety.

As a result of the recruitments in 2004-2006 the European Commission approved 45 Polish projects in the area of environmental protection of the eligible costs of almost 2.3 billion euro with the participation of grants from the Cohesion Fund of 1.6 billion euro (Przedsięwzięcia Funduszu Spójności).

\section{Structural funds for environmental protection in Poland IN THE YEARS 2004-2006}

In the case of the structural funds the document which determines the direction and amount of financial support in Poland in the years 2004-2006 was the Community Support Framework (CSF) (Podstawy Wsparcia Wspólnoty). This document shows the strategy and priorities of the funds in every member state of the European Union, their specific objectives, the contribution of funds and other financial resources. CSF in Poland was implemented by five one-fund (Increase of Economic Competitiveness, Human Resources Development, Restructuring 
and Modernization of Food Sector and Rural Development, Fisheries and Fish Processing, Transport) and one two-fund sectoral operational program (Integrated Regional Operational Programme). Within this programme beneficiaries can apply for funding. Investments related to environmental protection could be financed primarily through two programs: the Sectoral Operational Program for Improvement of the Competitiveness of Enterprises (SOP ICE) and the Integrated Regional Operational Program (IROP). The main objective of the SOP ICE was to support the actions to increase the competitiveness of Polish economy and enhance its ability to function in the environment of open markets. This program was funded by the European Regional Development Fund (ERDF) and from national funds. The budget of this programme for the period 2004-2006 amounted to 2.8 billion euro, including ERDF funds accounted for about 1.25 billion euro. This programme was built based on two priorities: the development of entrepreneurship and innovation by strengthening the institutions of business environment and direct support to enterprises. Measures adopted under Priority 1 were to enable the creation of institutions (network of) the business environment to provide high quality services for businesses. Actions in priority 2 allow for improved competitive position of enterprises, in particular by improving their product offerings and technology. Actions related to environmental protection were implemented by the action 2.4 - Support for projects in the adaptation of enterprises to environmental protection requirements. The implementation of this action was the National Fund for Environmental Protection and Water Management. In action 2.4 there were implemented the following four:

-2.4.1 - integrated permit,

-2.4 .2 - water and sewage,

-2.4 .3 - air protection

- 2.4.4 - waste management.

As a result of the period of January 2005 - June 2006 there were five rounds of selection of grant applications signed with 249 entrepreneurs. The value of the agreements signed was 743 million PLN (see Table 3).

Among 249 projects which have received support, 106 related to an integrated permit, 73 to waste management, 53 to water and sewage, and 17 to air protection.

The aim of the Integrated Regional Operational Program was the creation of conditions for the competitiveness of regions and preventing the marginalization of certain areas in such a way as to foster a permanent economic development of the country's economic, social and territorial cohesion and European integration. Implementation of the strategic objective was to encourage economic growth, structural transformation of the regions, the growth of urbanization, increased mobility of the population and increase spatial awareness and access to cuttingedge technology and public operators. 
Table 3. Summary of the recruitments in Action 2.4: Environment

\begin{tabular}{|l|c|c|c|c|c|}
\hline Round & $\begin{array}{c}\text { Value } \\
\text { reported } \\
\text { investment } \\
\text { in millions } \\
\text { of PLN }\end{array}$ & $\begin{array}{c}\text { Declared eligible } \\
\text { investment in } \\
\text { millions of PLN }\end{array}$ & $\begin{array}{c}\text { Requested } \\
\text { assistance in } \\
\text { millions of } \\
\text { PLN }\end{array}$ & $\begin{array}{c}\text { Number of } \\
\text { finally signed } \\
\text { agreements }\end{array}$ & $\begin{array}{c}\text { Value of the } \\
\text { signed agree- } \\
\text { ments in PLN }\end{array}$ \\
\hline I & 2221.8 & 2037.7 & 395.7 & 25 & 100797167.83 \\
\hline II & 1658.1 & 1622.2 & 501.5 & 66 & 229897907.9 \\
\hline III & 856.3 & 819.0 & 318 & 54 & 218745393.31 \\
\hline IV & 1536.0 & 790.0 & 232.9 & 43 & 81810327.76 \\
\hline V & 573.6 & 565.8 & 214.7 & 61 & 112029651.24 \\
\hline Total & 6845.8 & 5834.7 & 1662.8 & 249 & 743280446.04 \\
\hline
\end{tabular}

Source: own study based on the information of National Fund for Environmental Protection and Water Management, http://www.nfosigw.gov.pl/site/main/fundusze_strukturalne.php.

Achieving this objective is carried out through four priorities:

- expansion and modernization of infrastructure for strengthening the competitiveness of regions,

- strengthening human resources in the regions,

- local development,

- technical support.

The first priority contained an operation which was called 'environmental infrastructure'. The justification for intervention in the environmental field was the fact that investment in environmental protection is one of the key factors of sustainable development, helps improve the living conditions of residents and improve the attractiveness of regions. This action was intended to limit the amount of pollutants entering the air, water and soils, improvement of flood safety, increased use of energy from renewable sources, and improving environmental management. The result of achieving these goals would be improving the environment, improving the living conditions of people and creating favourable conditions for the development of enterprises operating in accordance with the principles of respect for the environment. Implementation of projects was to contribute to the attainment of the standards for environmental protection contained in the European Union Directives on the land transferred to Polish law. The activities for the projects were to have a positive impact on increasing economic and investment attractiveness, and comply with the standards of environmental protection required by the European Union. The activities were implemented in the infrastructure projects worth a total of 1 million to 10 million (in projects with a total value exceeding 10 million euro were eligible for subsidies from the Cohesion Fund, the environmental infrastructure projects with a total value of less than 1 million were realized under Priority 3 local development). To achieve 
success in this action there were also provided some funds for projects in the field of environmental management with a minimum total value of 1.2 million PLN.

The implementation of this action earmarked 307.4 million euro of ERDF (approx 1.4 billion PLN). All allocated funds for this activity have been used. It should also be mentioned that the activities related to environmental protection were also to a lesser extent, supported by other operational programs. In the case of Sectoral Operational Program Restructuring and Modernization of Food Sector and Rural Development under Action 2.6 development and improvement of technical infrastructure related to agriculture among the projects eligible for support include a project related to construction, renovation or upgrading of water supply facilities as well as network and equipment supply (including those from sources that are associated or renewable). However, it is impossible to identify clearly how much money has been earmarked to support projects related to environmental protection.

\section{Conclusions}

The analysis carried out shows that the funds spent on the implementation of the National Environmental Policy in Poland in the years 2004-2006 from the Cohesion Fund and Structural Funds totalled 2.1 billion euro. According to the official data provided by the Ministry of Regional Development for these years, the support including all the aid funds of the European Union (pre-accession, Structural and The Cohesion Fund) for environmental investment was 319.23 million euro (82 million in 2004, 85.25 in 2005 and 151.98 in 2006) (Raport z realizacji Polityki Ekologicznej Państwa). The Statistical Yearbook of Environmental Protection pointed out, however, that expenditure on fixed assets for environmental protection and water management of foreign funds amounted to $2926 \mathrm{mln}$ PLN (652.8 mln PLN in 2004; 955.4 million PLN in 2005 and $1317.8 \mathrm{mln}$ PLN in 2006) (Ochrona Środowiska, 2007, p. 431). The vast difference is due to the fact that the Ministry for the statistical purposes takes only those measures which have already been transferred to the beneficiaries by the end of the year, but not those which arise from the signed agreements. The estimated resources for the implementation of environmental policy from all foreign sources amounted to almost 11.7 billion PLN. So we can see clearly that these inputs were almost one-third less than projected.

Also, the total expenditure reported by the Central Statistical Office in 20042006 amounted to 18.2 billion PLN (Ochrona Środowiska, 2007, p. 431) while it was projected in the National Environmental Policy at the level of 50.8 billion PLN (Polityka Ekologiczna Państwa, p. 68). This shows that to achieve fully all the objectives set out in the environmental policy spending on environmental 
protection should be substantially increased. These expenditures were too low to fulfil entirely the accession obligations and implement all the legislative requirements in the field of environmental protection. During the accession negotiations, Poland indicated that aid funds ought to constitute the main source of funding for adaptation to the European Union regulations in the field of environmental protection. According to the National Environmental Policy (participation of foreign aid in the effort to protect the environment was expected to be: $25.6 \%$ in 2004, 23.4 \% in 2005 and $19.4 \%$ in 2006 Polityka Ekologiczna Państwa, p. 68). According to the Central Statistical Office data (Ochrona Srodowiska 2007, p. 431), these funds amounted to $12.2 \%$ in $2004,16.0 \%$ in 2005 and $19.1 \%$ in 2006. Practically, only in 2006 they reached the expected level. A positive aspect is that their participation is on increase. The analysis shows that the support of the European Union is an important source of funding the environmental policy in Poland. Without these measures it would not be possible to achieve the intended policy objectives. The exhaustive use of aid funds could become one of the main tools for implementing the provisions of the National Environmental Policy.

\section{REFERENCES}

Bernaciak A., Gaczek W. M., (2002), Ekonomiczne aspekty ochrony środowiska, Wyd. Akademii Ekonomicznej, Poznań.

Górka K., Poskrobko B., Radecki W., (1998), Ochrona środowiska. Problemy społeczne, ekonomiczne i prawne. PWE.

Information of National Fund for Environmental Protection and Water Management http:// www.nfosigw.gov.pl/site/main/fundusze_strukturalne.php, (as of 11 Septemer).

Ochrona środowiska 2007 (2007), GUS, Warszawa.

Podstawy Wsparcia Wspólnoty, Promowanie rozwoju gospodarczego i warunków sprzyjajqcych wzrostowi zatrudnienia, (2003), Bruksela-Warszawa, Document accepted by The Council of Ministers on 23 December 2003 and accepted by the European commissionon 22 June, 2004, http://www.funduszestrukturalne.gov.pl/NR/rdonlyres/3FAE9823-CD764125-A6E2-D7D340AB5E50/22278/pww_pl300805.pdf, (as of 17 September, 2009).

Polityka Ekologiczna Państwa na lata 2003-2006 z uwzględnieniem perspektywy na lata 2007-2010, (2002), Rada Ministrów, Warsaw.

Przedsięwzięcia Funduszu Spójności, (2009), http://www.nfosigw.gov.pl/site/main/fundusz_ spojnosci_odslona_bis.php?idg=1085144159\&id=1096543876 (stan na dzień 5 września).

Raport z realizacji Polityki Ekologicznej Państwa w latach 2003-2006, (2008), Rada Ministrów, Warsaw.

Sobiecki M., (2005), Finansowanie ochrony środowiska w świetle polityki ekologicznej państwa, Wydawnictwa Akademii Ekonomicznej, Cracow. 


\title{
Rola wsparcia Unit Europejskiej we wdrażaniu w Polsce zapisów Polityki Ekologicznej Państwa w latach 2004-2006
}

Słowa kluczowe: polityka ekologiczna państwa, Fundusz Spójności, fundusze strukturalne, nakłady na ochronę środowiska

\begin{abstract}
Abstrakt: Ochrona środowiska jest jednym z najważniejszych wyzwań współczesnego świata. Nie inaczej jest też w Polsce. Dokumentem, który określa cele i zadania i do realizacji w tym obszarze, jest Polityka Ekologiczna Państwa. W artykule przedstawiono, jakie są jej główne założenia. Pokazano źródła jej finansowania. Dokonano szczegółowej analizy w obszarze finansowania polityki ekologicznej ze środków pomocowych Unii Europejskiej. Przeprowadzone badania pokazały zbyt małe nakłady na ochronę środowiska, aby mogły w pełni zostać zrealizowane zapisy Polityki Ekologicznej Państwa.
\end{abstract}


